International Journal of Canadian Studies

Revue internationale d'études canadiennes

INTERNATIONAL JOURNAL OF CANADIAN STUDIES

REYUE INTERNATIONALE D'ÉTUDES CANADIENNES

\title{
Canadian Educators' Narratives of Teaching Multicultural Education
}

\section{Khalida Tanvir Syed}

Numéro 42, 2010

URI : https://id.erudit.org/iderudit/1002181ar

DOI : https://doi.org/10.7202/1002181ar

Aller au sommaire du numéro

\section{Éditeur(s)}

Conseil international d'études canadiennes

\section{ISSN}

1180-3991 (imprimé)

1923-5291 (numérique)

Découvrir la revue

Citer cette note

Syed, K. T. (2010). Canadian Educators' Narratives of Teaching Multicultural Education. International Journal of Canadian Studies / Revue internationale d'études canadiennes, (42), 255-269. https://doi.org/10.7202/1002181ar
Résumé de l'article

Cet article décrit les réussites et les défis caractéristiques de l'enseignement multiculturel de niveau supérieur dans les universités du Canada. Les critiques de l'enseignement multiculturel actuel ont centré leurs efforts sur la création d'un programme éducatif multiculturel à partir de sources littéraires et de méthodes pédagogiques de diverses origines culturelles. Ma méthode consistait à demander aux éducateurs de rédiger une analyse narrative sur les aspects fondamentaux de leur expérience de conception et d'enseignement d'un cursus multiculturel. Le multiculturalisme n'est plus une préoccupation propre aux minorités et aux immigrants, il est devenu une question sociale d'intérêt public. Les idées mises de l'avant et les connaissances acquises grâce à cette recherche pourraient servir de guide aux décideurs et aux éducateurs pour comprendre et aborder les caractéristiques du multiculturalisme en constante évolution, et ce, afin de vivre dans une société harmonieuse. 


\title{
Khalida Tanvir Syed
}

\section{Canadian Educators' Narratives of Teaching Multicultural Education}

\begin{abstract}
This article describes the challenges and accomplishments of teaching multicultural education in graduate courses at Canadian universities. Critics of current multicultural education have focused on creating a multicultural curriculum from culturally diverse literary sources and teaching methods. My focus has been to ask educators, through narrative inquiry, about critical aspects of their experiences of designing and teaching a multicultural curriculum. Multiculturalism is no longer a concern of minorities and immigrants; it has become a social issue of concern to all. The insights and knowledge gained from this research may guide policy makers and educators to understand and address the ever-changing characteristics of multiculturalism in order to live in a harmonious society.
\end{abstract}

\section{Résumé}

Cet article décrit les réussites et les défis caractéristiques de l'enseignement multiculturel de niveau supérieur dans les universités du Canada. Les critiques de l'enseignement multiculturel actuel ont centré leurs efforts sur la création d'un programme éducatif multiculturel à partir de sources littéraires et de méthodes pédagogiques de diverses origines culturelles. Ma méthode consistait à demander aux éducateurs de rédiger une analyse narrative sur les aspects fondamentaux de leur expérience de conception et d'enseignement d'un cursus multiculturel. Le multiculturalisme n'est plus une préoccupation propre aux minorités et aux immigrants, il est devenu une question sociale d'intérêt public. Les idées mises de l'avant et les connaissances acquises grâce à cette recherche pourraient servir de guide aux décideurs et aux éducateurs pour comprendre et aborder les caractéristiques du multiculturalisme en constante évolution, et ce, afin de vivre dans une société harmonieuse.

\section{Introduction}

This research paper is framed by the question: "What are the personal and pedagogical experiences of Canadian educators ${ }^{1}$ who engaged with the challenges of teaching multicultural education in their graduate courses?" Since the Multiculturalism Act in Canada, many educators and scholars have responded to the policies articulated in the Act. Currently there exist many understandings of the meaning of "multicultural." As Kincheloe and Steinberg point out, multiculturalism means different things to different scholars, each representing a particular view of issues of race, socio-economic status, gender, 
language, religion, and culture. The diverse meanings and views of what is meant by "multicultural" added to the complexity of my search to learn how Canadian educators designed and taught their multicultural curriculum. The multifaceted Canadian population, which is evident in contemporary classrooms, makes this research both urgent and challenging. Not only is this research of significance in Canada, the United Nations' Education officials (Inglis) recommend the inclusion and promotion of multicultural education worldwide.

\section{Theoretical Framework}

Multicultural education has had a different focus in Canada, Britain, and the United States since the 1980s (Modood). Until the 1980s, in Britain and Canada, multicultural education focused on other cultures as "them." This discourse obscured issues of inequality and emphasized the "us/them" discrepancy between colonial powers and subjugated peoples by limiting cultural study to aesthetic aspects of representation at the expense of socio-political realities (Said, Culture and imperialism, Orientalism). Multiculturalism until the 1980s has been described as having an emphasis on the aesthetic experiences frequently critiqued with the phrase "the three F's-food, film, and festival." Limiting cultural study to aesthetic aspects, such as whether or not you eat samosas or poutine, or wear an eagle feather or a cowboy hat, limits possibilities for going beyond issues of inequality and power. It also limits the exploration and questioning of the identity of "us" and "them." A theoretical framework that acknowledges multiculturalism beyond the aesthetic aspects of representation brings other voices to the discourse and honours stories and experiences of diversity.

Ungerleider states that decision makers and academics who establish and analyze "real world policies" should rethink their values, and become aware of the importance of "contextual sensitivity and temporal immediacy" (xiv). He goes on to say that "the state can neither eradicate ethnocultural identifications that provide salient points of self-reference or attachments for those who wish to retain them, nor cause them to flourish when they no longer serve us" (xiv). Decision makers and academics are members of the community of "us," that is, people in positions of power. By addressing inequalities, we can bring social justice and change to Canada; but to do so, we must examine the intersecting complexities of multiculturalism in education.

The three most common approaches to multiculturalism are conservative, liberal, and critical multiculturalisms (Kincheloe and Steinberg). Conservative multiculturalism refers to a monocultural belief in the superiority of Western, white culture as the standard to which other cultures are compared. An important aspect of conservative multiculturalism is the effort to assimilate all into white, North American standards and values in the belief that differences 
from these standards constitute deficiency or deprivation, and assimilation is considered a positive outcome of intercultural contact. Kincheloe and Steinberg state that the monoculturalist position is essentially one of power, as dominant groups tend to respond in defensive and protective ways whenever cultural (power) hegemony is threatened.

Liberal multiculturalism focuses on the equality of diverse peoples (Banks; Ghosh). Differences of race, culture, and gender are viewed as less important than the similarities all people share, leading to the promotion of a color blind society in which the facets of culture are not barriers to happiness and success. Consequently, liberal theorists have been reluctant to engage in any critical analysis of power (Kincheloe and Steinberg); and liberal multicultural discussions and practices often focus on idealized and exoticized lists of the differences between "us" and "them." Liberal multiculturalism's focus on "equality" and "political correctness," therefore, may merely gloss over the real concerns that it was meant to address. As a result, Kymlicka questioned the long-term sustainability of "liberal multiculturalism" (15) with its under-emphasis on difference and inequality: "We need to be conscious of the pre-conditions that make those practices possible, and then think of the various ways that international organizations can help achieve them" (Kymlicka 313). $\mathrm{He}$ advocates developing connections between existing legal norms (such as the Canadian Multiculturalism Act) and the academic theory and practice of "liberal multiculturalism" (315). Developing connections between the theory and practice of liberal multiculturalism leads to implications for how we look at ourselves and others, and how we relate to each other in a diverse society such as Canada.

More than a decade ago, Giroux (Ideology; Border) critically assessed the role of dominant white culture in marginalizing others through relations of power and knowledge distribution. This critical-assessment approach prioritizes the politics of difference in gender and race (Sleeter). Critical multiculturalist researchers connect different kinds of oppression, and emphasize equity within the dynamics of difference. This is not to say that critical multiculturalism is merely "oppression studies," the polar opposite of conservative multiculturalism, but rather that the critical multiculturalism attempts "to make the pedagogy political" (Kincheloe and Steinberg 28) in order to produce social change that is beneficial to all.

In his book Breaking the Mosaic, Young notes that the "mosaic" model of Canadian multiculturalism, having been influenced by a post-colonial attitude toward Canadian nationality, is no longer adequate. In order to change relations and meanings, dialogues between dominant and minority groups should connect the life experiences of student teachers and educators. Multiculturalism is often not given the attention in teacher education 
curricula that it deserves (Cochran-Smith). Zinga describes the current state of the Canadian education system as follows:

The vast majority of Canadian schools continue to teach from a Eurocentric curriculum and despite attempts to incorporate "multicultural education" into these systems, the systems primarily serve to perpetuate the illusions to students that Canada is the country of the white majority. . . The curriculum within Canada's educational systems is out of step with the realities of Canadian life and is not adequately serving its students. (210)

Even within the curriculum that is used, the Eurocentric curriculum in Canadian schools does not adequately address the realities of student life. Guo and Jamal recommend the integration of multicultural and anti-racist education in order to promote critical reflection at the individual, classroom, and institutional levels, and nurture cultural diversity in the day-to-day lives of academics. Gallavan has suggested that "more research needs to be conducted regarding the instructors of these [multicultural] courses - their challenges, conflicts, and coping skills" (11). According to Florio-Ruane, examining cultural narratives inspires educators to relate their own cultural locations to those of their students. Narrative inquiry is one such methodology that facilitates this research.

\section{Methodology}

Narrative inquiry is a time-honoured and accessible way of sharing knowledge that facilitates intercultural dialogue: stories challenge barriers through shared experiences. Through the methodology of Narrative Inquiry, I engaged in conversations with four educators from four Canadian universities, focusing on some of the tensions and struggles they encountered and strategies they developed in their teaching. Clandinin and Connelly's statement that narrative inquiry is a useful methodology for exploring teachers' stories informed my approach. As White argues, narrative helps us to understand and make meaning of human experience; the significance of narrative to teaching multicultural education forms the basis of my research. My participants were an English male professor in Manitoba, a South Asian female professor in Quebec, an Aboriginal female professor in Quebec, and a francophone female professor in Alberta. For the past 25 years, they have been teaching multicultural graduate courses, ${ }^{2}$ with the goal of increasing awareness and sensitivity to cultural differences. I met these educators after their conference presentations and asked if they would engage in in-depth conversations with me. I chose these individuals because they were well known in the North American academic community for their contributions in promoting multicultural education through their writing and teaching. I wished to include voices that might provide insight into diverse perspectives on multicultural education. 
The educators provided me with their course outlines. I visited them at their universities and recorded 12 hours of conversations (3 hours per session) with each of them over a period of 6 months, spending 6 weeks at each site. After transcribing the interview data, and as I began to write the research text, I continued conversations by email and telephone for 6 months, clarifying language, terms, and content. My focus was on their 25 years of personal and pedagogical experiences and how these related to the promotion of multicultural approaches within teacher education programs. The final drafts of my interpretations were shared with all participants by sending hard copies for their approval of the data, for clarification, and for authentication purposes.

During this process, the text was "subject to multiple interpretations, multiple readings, multiple uses" (Lather vii) — and allowed the participants of this study to enter into and construct their own meanings from their narratives of experience. According to Apple, the purpose of this type of post-modern work is to engage in "open-endedness, dialogue, explicitness and reciprocity" (x). The narratives I present in this research should provide readers with models to incorporate multicultural narrative inquiry in their own work.

\section{Canadian Educators' Perspectives}

The four professors interviewed for this study articulated their understanding of multicultural education in diverse ways, clarifying and legitimating their use of terms such as multicultural, intercultural, cross-cultural, and transcultural. Even this usage of diverse terms is a window into the complexity of Canadians' ways of living together. There were similarities and differences in their instructional strategies and teaching practices, and in their challenges and accomplishments. I am presenting their voices/narratives ${ }^{3}$ one by one to maintain the coherence of their distinctive perspectives.

\section{Jay: An English Perspective}

The first participant is a white male professor who immigrated to Canada from England in the 1980s. He described multicultural education as a term used in a broad range of ways. For him, "Multicultural education can be viewed as a social reconstructionist concept. It is essential to engage in critical discourse and is up to the skills of the instructor to teach, potentially to engage in a way that transforms stereotyping." This professor described his current graduate administration course as "an attempt to incorporate diverse perspectives and issues of multicultural education into a mainstream administration course." This enabled him to bring "issues of equity and diversity into administration courses rather than teaching multicultural courses on their own." He builds critical theory into the planning of his courses. For example, he invites guest speakers to talk about issues relating to diversity. "They can't be my White, male friends. I try to keep that template of diversity up front and centre." 
He ensured representation from Aboriginal and minority communities. $\mathrm{He}$ invited representation from school superintendents, principals, and faculty in other disciplines such as Sociology. His purpose was to create "a balance between a climate of openness and trust, and challenging, confronting, and criticizing."

He experienced some challenges in the form of time constraints.

It is a challenge, in 13 weeks, to incorporate diverse perspectives and issues. Why would you expect students to come to your class knowledgeable about a topic that has taken you 25 years to become knowledgeable about? I have questioned how we become knowledgeable. Is it about exploring your own bias, cultural, class, and, gender locations? Is it a process involving meeting with people from various communities? Students need an experiential and theoretical background.

Another challenge occurred in the form of resistance from students, which he experienced primarily when students' thoughts and opinions were dismissed rather than engaged.

We cannot criticize or silence graduate students for stating their opinions. I think students who resist but engage, are doing what the university is about. Students are involved in a critical discourse and it is up to the skills of the instructor to teach so that their instruction enables students to transform stereotyping. These conversations require a two-way dialogue that is respectful of the student and opens the possibility of both professor and student refining their perspectives, not just the student getting it right.

His process of curriculum design, instruction, and dialogue is ongoing. His accomplishment lies in being able to sustain and encourage the conversations that stimulate questioning and critical thinking. For Jay, the successful promotion of multicultural education depends on three primary factors: collaboration, diversity, and critical engagement.

\section{Rana: A South Asian Perspective}

The second participant, Rana, is a South Asian female educator in Quebec. Historically and politically, Quebec is in a unique position in relation to the other provinces and territories. At the time of Confederation in 1867, Quebec was granted special rights that were written into the Constitution. In Canada, education is a provincial responsibility and education policies differ in each of the provinces. However, there is a sharing of expenditures and support of public education between the provinces and the federal government. Rana explained:

The federal policy has been aimed at making Canada a "just" society. The implementation of this policy in education in English-speaking 
Canada has been far from satisfactory, and there is a great variation among the provinces. In Quebec, the federal policy of multiculturalism is ideologically opposed to the vision of French-Quebecois nationalism. While the federal policy of multicultural education has made some attempts to integrate immigrant populations, the focus remains on linguistic programs.

Rana presented her perspective on some of the significant factors to consider when designing and teaching courses, and her perspective on the challenges and accomplishments that academic administrators and educators may experience in promoting and developing a critical multicultural curriculum and pedagogy.

The first factor Rana introduced into our conversations centred on the meaning of the word "multicultural."

Some faculty members still think multiculturalism is a song and dance routine. I think the important point is to understand multiculturalism as more than ethnic cultures. In my mind multiculturalism has nothing to do with ethnic cultures; it has everything to do with difference and how some differences make a big impact in terms of discrimination and racism, lack of access, lack of opportunities, differential treatment, oppression, vulnerability, all these things.

It is essential, she says, to be aware of the subtle meanings and the emotions attached to words. For example, when Rana designed a new course in multiculturalism in 1977, she used the word "inter-cultural" rather than "multicultural." "In Quebec 'multicultural' is not used simply because it is a federal government word and they don't use it." She explained this further, saying that

Quebec's intercultural policies are based on language learning. The francophone media stresses the value of speaking the French language. Legally, intercultural policy says that people can be different. However, whether it is English in Toronto or Calgary, or French in Quebec, you must learn the local language.

The local language attached significance to the distinction between the use of "intercultural" and "multicultural." However, there were still challenges, despite an awareness of the language concerns.

I proposed the intercultural course for teachers as an elective. First, I had trouble getting it through, but once it got through, students would not register. I inquired why students were not interested. I found out that their academic advisors told them not to take that course.

Rana was able to continue to offer the course and changes did occur, in part through her involvement with the English school board, helping to 
develop a policy on multiculturalism. When hiring an applicant, the board asked prospective teachers if they had intercultural education in their teachertraining program. Although Rana believed that "Just having a course on the books is not enough," the board's question as part of the hiring interview gave impetus to start intercultural education. The university realized they had to do something about it.

In designing and teaching her courses, Rana's objectives include informing her students about the value of understanding the definition of multicultural education, respecting and including difference, and ensuring that students will learn about and understand the relationship between knowledge, culture, power, and social policy, and be able to discuss these issues within the context of differences. There are challenges, as she says:

I won't say it's smooth going because sometimes we have very, very difficult students and situations, where two students may argue about something. But you get over them by pointing to something objective, for example, the Universal Declaration of Human Rights.

Rana's awareness of and sensitivity to language was a significant factor in the design, particularly as language is identified in the context of historical and present political and cultural power relations. The challenging factor of tensions in classrooms when these issues become part of the classroom discussion, structured through the design of the course, is to be accepted and overcome by focussing on the larger picture, as Rana points out, to the Universal Declaration of Human Rights. In summary, Rana's strategies for promoting multicultural education emphasize awareness of regional differences (between Quebec and English Canada), faculty involvement, and student participation.

\section{Eveline: Aboriginal Perspective}

Eveline says that for her, "Multiculturalism is an interconnection of cultures. Each culture and experience enriches other's lives. I walk the world with a moccasin on one foot and a shoe on the other." This last statement places Eveline in the world, not merely in Canada. She says,

The First Nations who are here in this country are in themselves multicultural. We were multicultural long before multiculturalism became official policy. Even when we had conquerors arriving, we didn't have the experience of shutting out a particular group; the elders taught us that the weak of other tribes needed to be helped. Whether it was a wise thing for my ancestors to accept all of the Westerners that came here or not is the question. Historically, Aboriginal people have been open, receptive, and sharing. It is not racist. It is accepting. However, because of their political definitions, the words "multiculturalism" and 
"diversity" have negative connotations among First Nations people. I think we need to find new vocabulary. Indian people always feel we were here first and were not immigrants and multiculturalism equals immigration. I decided to become more intensely active on anti-racism, because multiculturalism is a gentle term. Multiculturalism seemed like a nice way to keep those "different people" quiet. You can't talk about race and racism; we are loved because we are so multicultural. Multiculturalism is a nice cocktail topic in Ottawa. It's something like a slogan.

Eveline claims that Canadians need to go beyond the superficial acceptance of difference in which we celebrate multiculturalism with food and festivals, dancing, sharing Jamaican coffee, eating German potato salad, and learning French. Successive waves of immigration have transformed Canada. In the 1950s Eastern European, Italian, Greek, and Portuguese came. Vietnamese, Cambodian, and Laotian arrived in the 1960s and 1970s; South Asian and Haitian in the 1980s; and Middle Eastern and South American in the 1990s. Between 1968 and 2000, many new Canadians were members of visible minorities. While these changes have been occurring, Eveline says that

The one thing that has been constant is the inability of our education system to react. Since the institutionalized imposition of English around 1920-40 stopped the progress of Aboriginal languages, many children could still understand their parents but did not use their languages, so these languages were erased. Although Aboriginal peoples in general lost their stories, histories, languages, and cultures, my family always kept our stories and certain other cultural values. Every story had a lesson. Wisdom came from these stories. If I have an opportunity to share the stories, then I call myself a teacher. Now, I'm extremely hopeful that the present generation will maintain their culture and know who they are, but will also succeed in the modern world. We need a voice. We need to be present in the classroom. We need to have our story told, but our kids, particularly reserve-level kids, also need to participate in Canadian multicultural society.

The way voice is expressed and stories told, and the ways in which the children will participate in the future of a Canadian multicultural society are significant. As Eveline expresses this:

If we insist that our voice has to come first, if we become almost radical in the effort to maintain our culture and identity, we're going to isolate ourselves from the rest of the world.

The roots of racism are ignorance and fear of the unknown. The ignorance generates fear and the fear causes racism and it's a circle. The solution is to treat difference as a way of interacting with the other and as an enriching teaching experience. Rejecting the modern world because it is white and Western is arrogant; children who are not 
taught to live in the twenty-first century will never experience the joy that can be found in an urban setting.

If difference is a way of interacting with the other and in this way is perceived as an enriching teaching and/or learning experience, then isolation from any "world" diminishes living. During the Oka crisis in 1990, Eveline and her husband, who is a French Canadian, were concerned when they observed their son isolating himself from his Aboriginal culture. She said, "My son, a redhead, refused to wear the Indian jacket his grandfather gave him. He was the symbol of what many children experienced that summer: they knew who they were, but were treated differently because of their identity." In order to encourage future generations from multicultural, urban, and Aboriginal communities to be part of the global picture in the way that Eveline is, with a moccasin on one foot and a shoe on the other, educational institutions must assume more responsibilities. The deans in all faculties need to leave their "ivory towers and go and talk to children. Educators need to practice what they preach."

Eveline observed that "Alberta is the place right now to understand multiculturalism." She suggested that in order to go beyond the superficial acceptance of differences that she sees in multiculturalism, the new vocabulary should include the word "interculturalism." This is a softer understanding of the term. For example, the Hoop Dance provides an image of circles intersecting. Circles mix and intersect, connecting and entering into other worldviews as opposed to being distinct and separate. The image of the Hoop Dance's intersecting circles is a useful representation of Eveline's views of multicultural education as a reality for all Canadians, Aboriginal, and non-Aboriginal alike.

\section{Claudine: A Francophone Perspective}

Claudine believed that context was very important. She lived in several communities as she grew up; in some of these communities francophones were a minority.

Growing up, I had heard all sorts of insults against French Canadians, remarks about the large families and about how we just sing and dance and make babies. I found out later that this was like what people said about the blacks in the United States, so these are stereotypes about minorities. And I didn't think that they fit. In any community, Aboriginal, francophone, and elsewhere, if somebody stands out too much, there is terrible jealousy and people will attack the ones they are jealous of. This is the dark side of community. A community can be supportive, but it can also be stifling.

My parents insisted that we speak French. If we spoke to them in English, they would say, "What was that you said?" Grades 1 and 2 were entirely in French, and then English was added in Grade 3 
or 4; later on, I learned that this was what we could call "harsh assimilation" because it was done very quickly. In elementary school, we would have fistfights over which sections of the playground the French, English, German, and Ukrainian kids would use. Sometimes the teachers would scold us, but mostly they would leave us alone to sort it out ourselves. In Grade 7, all the French kids sat on one side of the room and all the English kids on the other, and the teacher's desk was on the English side. I was in Grade 9 when the kids from the Aboriginal residential school were integrated into the public school. The superintendent came to visit and told us that if he caught any of us bothering those Aboriginal kids, he would see us personally. There were no incidents against the Aboriginal kids; mostly we observed them and kept our distance. There was no effort made to integrate them.

Claudine had many definitions of multiculturalism. She explained that in francophone communities, in a minority context, she learned not to talk about "minority francophones." The reason was that it was important to distinguish between the context and the people. The context represents the other as an other. In her writing, she learned "not to use the "us/them" dichotomy and not to refer to other groups as "them." Using "them" immediately created a binary or opposition because it set her apart from them. For Claudine, multiculturalism was

intended for those who are different. A first reaction on hearing the word "multiculturalism" is an interpretation of meaning indicating somebody who is coloured or different or marked in some way. We've become more sophisticated, realizing that multiculturalism involves everyone. For those who are part of the dominant group, the task is to accept and include; for those in minority positions, the task is to know themselves, be strong, and find a place for themselves.

Claudine explained that a choice of words, and the meaning attached to the words, sets the definition and thus the meaning of the discourse. This, in turn, "determines the policy of multiculturalism. It's a policy that is a bilingual framework, an Official Language Act. The Multiculturalism Act and the Charter create the legal and policy framework." Having given this background, she went on to explain,

Intraculturalism is the term used in Quebec in reaction to the federal policy of multiculturalism and a wish to be separate and distinct. Some of my work has been in transculturalism, transculturation rather. The term was invented by Ortiz, a Cuban anthropologist, to describe the mixing of elements and creation of something new that was going on in the New World, not the same as by countries of origin. 
Claudine said that she had always been interested in language and culture. Further, in her words, she described multiculturalism as the name of a policy that makes it possible to have two official languages and to include and respect other languages although they are not official and do not have the same status. They have been devalued if you look at it critically, while still permitting people to live in those languages and cultures in Canada. Like Rana, Claudine is concerned about the terminology employed in multicultural discourse in Quebec; she prefers the term "transculturalism," which she regards as less politically loaded. She supports multi/transcultural policies in which no group or individual is overlooked.

\section{Discussion and Analysis}

The contribution made in this research suggests that there are several critical aspects involved in inter/multicultural education. First is that the meanings and definitions of multiculturalism vary. The four participants defined multiculturalism and multicultural education in different ways. These definitions were influenced by their cultural backgrounds and life experiences. While there is some common ground between their responses, their varying definitions (as transformative force, as awareness of differences, as connections between cultural groups, and as historical progression) illustrate the polyphony of voices in the educational profession and in Canadian society as a whole.

Jay did not provide a fixed definition of multiculturalism, but he does speak of it in terms of its transformative effects on society. Rana defines multiculturalism in terms of difference, especially the negative social effects of difference. Eveline defines multiculturalism in terms of interaction and connections between different cultural groups. Claudine gives a contextual, historical definition of multiculturalism, from its early emphasis on differences to the present realization that it involves everyone.

Second, there are challenges faced by each participant, and these are different for each. Jay was concerned with challenges of limitations on time in teaching courses. Rana presented challenges related to the understanding and expression of differences in class. Eveline used the metaphor of a hoop dance to illustrate the interconnected contributions of all cultures to the greater society. Claudine presented an awareness of meaning in language.

Third, all participants recognized the importance of opening critical yet respectful dialogues. Each approached this fundamental concern in a different way. One stated that students should be free to question authorities while another stressed the responsibilities of teachers to engage in critical discourse with students. The third emphasized the necessity of funding and support in the university community, and the fourth discussed the role of provincial and federal governments in supporting language and culture. 
Lastly, the participants saw the importance of self-critique in the process of multicultural education. They understood the necessity for diversity and fairness, and the need to use differences as learning experiences rather than fall back on simplistic "not like us" definitions. They also offered critiques of multiculturalism itself, noting the promotion of English and French as "official" languages, often at the expense of languages other than those. Respectful interaction, not binary "us vs. them" opposition, is the first step in creating a truly multicultural society. A multicultural society requires respectful interaction between members of the different communities within that society.

In understanding the ever-changing complexities, it is important to know diverse perspectives on the theoretical and historical background of multiculturalism. Acquiring this understanding and knowledge requires a commitment to the ongoing process of reflection that encourages awareness of one's own experiences, responsibilities, and rights. Courses need to be designed collaboratively within a faculty, encouraging colleagues, graduate students, and community representatives to think critically within open-ended conversations. Within the courses, it is essential to challenge traditional and past teaching and learning practices of both educators and students, and to expect and respond to constant change. The participants of this research have shown ways to incorporate these aspects into their teaching practices.

My purpose in undertaking this research is to offer insights that others will find helpful as they develop culturally sensitive pedagogy and curricula for educators, for pre-service and in-service teachers, and for all members of Canadian society. The "real-world" experiences of educators who integrate multicultural education into their academic work and pedagogical practices should provide inspiration to educational policy makers. This project and the stories gathered in this research will encourage awareness, understanding, and sharing social values among Canadian educators and their students, thus opening channels for constructive dialogue and change. In addition, reading about the experiences and achievements of my informants may encourage all Canadians, especially immigrants and descendants of immigrants, to pursue careers in teaching and teacher education, thus providing positive role models to schoolchildren and bringing in positive multicultural perspectives. As the experiences of my participants demonstrate, continuous critical reflection will assist in the promotion of a more just and harmonious society by helping to overcome stereotypes about cultural differences. 


\section{Notes}

1. By "educators," I am referring to professors in a university setting. I use "teachers" to refer to those who work with the general student population.

2. To protect the privacy of my participants I have used pseudonyms and not provided the titles of their courses.

3. Participants' narratives emerged from transcribed interview conversations, reformatted into continuous prose.

4. Spoken" grammatical conventions (contractions, slang, etc.) and errors (pluralities, gender indicators) were converted and/or corrected where appropriate, with consultation between the researcher and participant to preserve the meaning of original responses.

\section{Works Cited}

Apple, M. W. "The Culture and Commerce of the Textbook." The Politics of the Textbook. Eds. M. W. Apple and L. K. Christian-Smith. New York: Routledge, 1991: 22-40.

Banks, J. A. (2000). Multicultural education: Historical development, Dimensions, and practice. In J. A. Banks and C.A. McGee Banks (Eds.). Handbook of research on multicultural education. New York: Jossey-Bass.

Canada. The Canadian Multiculturalism Act (1985). 23 June 2004 $<\mathrm{http}: / /$ laws.justice.gc.ca/en/c-18.7/31859.html $>$.

Canada. The Canadian Charter of Rights and Freedoms (1982). 20 August 2004 $<$ http://laws.justice.gc.ca/en/charter>.

Clandinin, D. J. and Connelly, F. M. Narrative Inquiry: Experience and Story in Qualitative Research. San Francisco: Jossey Bass, 2000.

Cochran-Smith, M. Walking the Road: Race, Diversity, and Social Justice in Teacher Education. New York: Teachers College P, 2004.

Florio-Ruane, S. Teacher Education and the Cultural Imagination. Mahwah, NJ: Lawrence Erlbaum, 2001.

Gallavan, N. P. "Multicultural Education at the Academy: Teacher Educators' Challenges, Conflicts, and Coping Skills." Equity and Excellence in Education 33.3 (2000): 5-11.

Ghosh, R. Redefining Multicultural Education, 2nd ed. Toronto: Harcourt Brace, 2002.

Giroux, H. A. Border Crossings: Cultural Workers and Politics of Education. London: Routledge, 1992.

Giroux, H. A. Ideology, Culture, and the Process of Schooling. Philadelphia: Temple UP, 1981.

Guo, S., and Jamal, Z. "Nurturing Cultural Diversity in Higher Education: A Critical Review of Selected Models." Canadian Journal of Higher Education 37.3 (2007), 27-49.

Inglis, C. Multiculturalism: New Policy Responses to Diversity. 27 April 2004 $<$ http://www.UNESCO.org/most/pp4.html $>$.

Kincheloe, J. L., and Steinberg, S. R. Changing Multiculturalism. Philadelphia: Open UP, 1997.

Kymlicka, W. Multicultural Odysseys: Navigating the New International Politics of Diversity. New York: Oxford UP, 2007.

Lather, P. Getting Smart: Feminist Research and Pedagogy With/In the Postmodern. London: Routledge, Chapman \& Hall, 1991. 
Modood, T. Multiculturalism. Malden, MA: Polity Press, 2007.

Said, E. (1993). Culture and imperialism. New York: Alfred A. Knopf.

Said, E. (1978). Orientalism. New York: Pantheon Books.

Sleeter, C. E. "White Preservice Students and Multicultural Education Coursework." Developing Multicultural Teacher Education Curricula. Eds. J. M. Larkin and C. E. Sleeter. Albany: State U of New York P, 1995: 17-30.

White, Hayden V. "The Value of Narrativity in the Representation of Reality" On Narrative. Ed. W. J. T. Mitchell. Chicago: U of Chicago P, 1988.

Ungerleider, C. S. "Foreword" to Multicultural Education Policies in Canada and the United States Eds. R. Joshi and C. Johnson. Vancouver: U of British Columbia P, 2007: ix-xiv

Young, J. "Introduction" to Breaking the Mosaic. Toronto: Garamond P, 1987.

Zinga, D. (2006) Navigating Multiculturalism: Negotiating Change, (pp. 142-159). Cambridge Scholars Press: Newcastle, UK. 